\title{
Addressing Modern Slavery in Supply Chains: An Awareness-Motivation-Capability Perspective
}

\author{
Ruoqi Geng, Cardiff University \\ Kin-Sang Lam, University of Liverpool \\ Mark Stevenson, Lancaster University
}

\begin{abstract}
Purpose: There is still significant variation in firms' efforts to address modern slavery issues in supply chains despite the importance of this grand challenge. Our research adopts the Awareness-Motivation-Capability (AMC) framework to investigate AMC-related factors that help to explain this variation.

Design/methodology/approach: We hypothesize how AMC-related factors, including media coverage of modern slavery issues, slavery risks in supply chains, and corporate sustainability performance, are related to firms' efforts to address modern slavery in supply chains. The proposed hypotheses are tested based on 201 UK firms' modern slavery statements and additional secondary data collected from Factiva, Factset Revere, The Global Slavery Index, Worldscope, and Sustainalytics.
\end{abstract}

Findings: Consistent with the AMC perspective, our test results show that firms put more effort into addressing supply chain modern slavery issues when there is greater media coverage of these issues, when firms source from countries with higher slavery risks, and when firms have better corporate sustainability performance. Our additional analysis further suggests that firms' financial performance is not related to their efforts to address modern slavery issues.

Originality: This is the first study adopting the AMC framework to investigate firms' efforts to address modern slavery in supply chains. This investigation provides important implications for researchers studying firm behaviors related to modern slavery issues and for policymakers designing policies that enable firms to address these issues, in view of their awareness, motivation, and capability.

Keywords: Modern slavery, social sustainability, AMC framework, secondary data analysis.

Paper type: Research paper. 


\section{Introduction}

The COVID-19 pandemic has increased the vulnerability of workers to modern slavery, an umbrella term used to refer to "the recruitment, movement, harboring or receiving of children, women or men through the use of force, coercion, abuse of vulnerability, deception or other means for the purpose of exploitation" (Such et al., 2020, p. 217). In particular, enforced lockdowns across the globe, facility closures and massive layoffs have put workers at greater risk of exploitation, e.g. in terms of overtime, being underpaid, forced labor and other forms of modern slavery (Anti-Slavery International, 2020). Even before the pandemic, there had been various high-profile examples of modern slavery events in global supply chains, including those related to the Rana Plaza building collapse and the Tazreen factory fire in Bangladesh, and forced labor in, for example, the fishing industry in Thailand and cocoa farming in West Africa (Crane, 2013; Gold et al., 2015; Jacobs and Singhal, 2017; Stevenson and Cole, 2018). The consequences of modern slavery go far beyond reputational damage and financial penalties for focal firms (Butler, 2020; Jacobs and Singhal, 2017) - human lives are placed in jeopardy. Thus, government agencies, non-governmental organizations (NGOs) and the public are more concerned than ever about what firms are doing to address modern slavery in supply chains.

Despite the importance of addressing modern slavery in supply chains, there is still significant variation in firm efforts to address these issues. For instance, an analysis of FTSE 100 companies' modern slavery statements conducted by the Business \& Human Rights Resource Centre (BHRRC) revealed that only a small number of FTSE 100 companies reported and demonstrated rigorous actions to address modern slavery, while "the rest produced weak statements, indicating little action" (BHRRC, 2017, p. 1). Existing modern slavery-related legislation, such as the UK Modern Slavery Act (MSA), has also been criticized by practitioners for its inability to force firms to address modern slavery because it takes a soft legislative approach that encourages self-regulation rather than imposing sanctions (Ionova, 2018; Cousins et al., 2020). Although the extant literature has well documented the variation in firms' practices and efforts to address modern slavery, little is known about why such variation occurs (Monciardini et al., 2021). This prompts our research to investigate the following question:

$R Q$. What factors explain the variation in firms' efforts to address modern slavery in supply chains?

We leverage the Awareness-Motivation-Capability (AMC) framework (Chen, 1996) to investigate AMC-related factors that help explain the variation. The AMC framework fits our research context as it emphasizes that a firm responds to a competitive action when it is aware 
of the action, motivated to respond, and capable of responding (Chen et al., 2007). In context, this suggests that the extent to which a firm addresses modern slavery issues in its supply chain may depend on whether it is aware of the importance of addressing such issues but also on whether it has the motivation and capability to address them. Considering the three dimensions of awareness, motivation, and capability also enables us to provide a more comprehensive explanation of firms' efforts to address modern slavery in supply chains.

Following the AMC framework and informed by the modern slavery literature, we theorize that firms are more aware of the importance of addressing supply chain slavery issues when there is greater media coverage of these issues. Moreover, firms should have a higher motivation and capabilities to address these issues when they source from countries with higher slavery risks and have better performance in corporate sustainability, respectively. Consequently, we hypothesize that modern slavery media coverage, supply chain slavery risk, and corporate sustainability performance are positively related to firms' efforts to address modern slavery in supply chains.

Empirically, we take advantage of the modern slavery statements issued by UK firms under the UK MSA to quantify their efforts to address modern slavery in supply chains. We supplement this with secondary data on the same firms from multiple additional sources, including Factiva, FactSet Revere, The Global Slavery Index, Worldscope, and Sustainalytics, to measure other explanatory variables such as modern slavery media coverage, supply chain slavery risk, and corporate sustainability performance. Our regression analysis based on these secondary data provides empirical support for the proposed hypotheses. Our findings are robust to alternative variable measurements and to endogeneity concerns. Moreover, our additional analysis further suggests that firms' financial performance is not related to their efforts to address the slavery issues.

Our research represents the first study adopting the AMC framework to investigate firm efforts to address modern slavery in supply chains. This investigation advances our understanding of firms' modern slavery-related behaviors and contributes to the literature that has documented the variation in firm efforts to address modern slavery but "struggle[d] to explain it" (Monciardini et al., 2021, p. 290). Our additional analysis reveals the heterogeneity of the relationships between different types of firm performance and firm efforts to address modern slavery, inspiring researchers to further examine the explanatory powers of other AMC-related factors. Moreover, our research provides important implications for policymakers, i.e. to design policies that enable firms to address modern slavery in view of their awareness, motivation, and capability. 


\section{Literature Review and Theoretical Background}

\subsection{Modern Slavery in Supply Chains}

Researchers in supply chain management (SCM) have paid much attention to the management of social issues such as health and safety, human rights, gender diversity, and minority development in supply chains (Awaysheh and Klassen, 2010; Yawar and Seuring, 2017; Mani et al., 2020). For instance, Awaysheh and Klassen (2010) investigated how a firm's supply chain structure is related to its adoption of supplier socially responsible practices, while Mani et al. (2020) revealed a positive relationship between these socially responsible practices and supply chain performance. Meanwhile, Yawar and Seuring (2017) developed a conceptual framework that explains both the stakeholder-related drivers and performance outcomes of firms' responsible supply chain strategies, ranging from communication and compliance to supplier development.

More recently, and especially after the introduction of the UK MSA, SCM researchers have started to shift their focus to modern slavery, a specific type of social issue in supply chains (Gold et al., 2015; New, 2015). Different from traditional corporate social responsibility (CSR), which is understood as "doing good" or "doing more than what is required by law" (Arya and Zhang, 2009, p. 1093), modern slavery, such as forced labor, human trafficking, and other forms of worker exploitation, is "illegal, often hidden, and involves a range of labor market intermediaries" (Caruana et al., 2021, p. 258) and it is viewed as "one of the most acute abuses of human rights in contemporary business practice" (Crane, 2013, p. 49). Such a distinction makes it challenging for researchers to conduct a direct investigation of modern slavery issues in supply chains due to personal safety concerns and the difficulty of obtaining reliable primary data (Gold et al., 2015; New, 2015; Meehan and Pinnington, 2021). This has resulted in what Caruana et al. (2021, p. 251) called the "sad and sorry state of a non-field", i.e. modern slavery research in business and management.

Nevertheless, the enforcement of relevant modern slavery regulations such as the UK MSA provides a rare opportunity for researchers to examine how firms respond (or how they prepare to respond) to regulatory disclosure requirements (Benstead et al., 2018; Meehan and Pinnington, 2021; Rogerson et al., 2020). For instance, Benstead et al. (2018) found that horizontal collaboration helps retailers gain a competitive advantage in responding to modern slavery legislation, while Meehan and Pinnington (2021) identified three types of ambiguity techniques, i.e. defensive reassurance, transfer responsibility and scope reduction, that have been adopted by UK Government suppliers in response to the UK MSA's disclosure 
requirements. In addition to organizational responses, recent studies have also explored how other stakeholder groups, such as investors and consumers, react to the introduction of modern slavery legislation (Cousins et al., 2020; Carrington et al., 2021).

Moving beyond disclosure requirements, some researchers have further examined firms' practices and strategies to address modern slavery in supply chains (Benstead et al., 2020; Stevenson and Cole, 2018; Flynn and Walker, 2021). For instance, Benstead et al. (2020)

suggested firms adopt a targeted audit approach for detecting supply chain slavery issues and to partner with local NGOs to remediate these issues. Flynn and Walker (2021) found that public firms implement various strategies, such as renewing firm policies, strengthening contract terms and establishing working groups, to reduce modern slavery risks. Although previous studies have demonstrated the heterogeneity of firm responses to disclosure requirements and the variation in firm strategies to address modern slavery in supply chains, little is known about why such heterogeneity and variation occurs. Indeed, as Monciardini et al. (2021, p. 290) observed, existing studies "only describe this phenomenon [i.e. a variety of organizational responses and strategies] but struggle to explain it". Our research aims to address this important knowledge gap by adopting the AMC framework to investigate AMCrelated factors that help explain why firms put different efforts into addressing modern slavery in supply chains.

\subsection{The Awareness-Motivation-Capability (AMC) Framework}

The AMC framework was originally developed by Chen (1996) in the context of competitive dynamics to explain the conditions underpinning inter-firm competition. Built upon the concepts of social cognition and organizational change, the framework proposes three behavioral elements that influence the decision-making of a firm: awareness, motivation and capability (Chen et al., 2007). It explains that a focal firm's competitive action is driven by its awareness of threats or opportunities thereby instilling the motivation to react as well as the capability to go on the offensive and 'attack' competitors (Chen, 1996; Chen et al., 2007). Since its formulation around 25 years ago (Chen, 1996), the AMC framework has been used by researchers in various business fields, such as strategic management and international business (Chen et al., 2007; Yu and Cannella, 2007; Haleblian et al., 2012) and, more recently, in the field of operations management (Udenio et al., 2018; Craighead et al., 2020) to make sense of firms' practices and strategies. For instance, Udenio et al. (2018) applied the AMC framework to study firms' awareness, motivation, and capabilities that make them more likely to adopt inventory agility practices in the presence of demand shocks, which in turn leads them to 
achieve better performance. The AMC framework has also been employed to study CSR in general and sustainable SCM in particular ( $\mathrm{Li}$ et al., 2020; Brockhaus et al., 2019). For example, Brockhaus et al. (2019) used the AMC framework to propose a competitive dynamics model that explains how AMC-related factors drive a firm to adopt a proactive supplier code of conduct, in view of its rival's supplier code of conduct.

In line with these studies, we see substantial merit in applying the AMC framework to understand firms' practices for addressing modern slavery in supply chains. First, viewing modern slavery in supply chains as a threat to firms, the AMC framework enables us to make sense of the firms' efforts to address such a threat in terms of whether they are aware of the importance of addressing the threat as well as the motivations and capabilities to address it. Moreover, consideration of the three dimensions of awareness, motivation, and capability allows us to provide a more comprehensive explanation of the variation in firm efforts and to lay a solid theoretical foundation for future modern slavery research. Finally, the adoption of the AMC framework provides a direct response to calls for studying firm motivations and capabilities in the modern slavery context (Gold et al., 2015; Crane, 2013; Caruana et al., 2021). For example, Gold et al. (2015, p. 491) suggested that researchers can explore "which resources and capabilities need to be developed within individual companies" for addressing modern slavery in supply chains.

However, although the AMC framework enables a comprehensive theoretical explanation of firm behaviors, it is difficult to measure awareness, motivation, and capability at the firm level, especially for research that is based on secondary data. Researchers thus need to make use of other relevant, measurable variables to indicate or signal a firm's awareness, motivation, and capability. This also suggests that these variables are context-specific and vary across studies. For example, Chen et al. (2007) used the relative scale of a firm's competitors to indicate the firm's awareness of the competition, whereas Udenio et al. (2018) employed a firm's market orientation to signal its awareness of demand shocks. Similarly, regarding the capability dimension, Udenio et al. (2018) chose a firm's availability of resources, such as planners and IT systems, in their research context of inventory management, but Haleblian et al. (2012) relied on a firm's financial performance to study its participation in an acquisition wave. Despite such variation across studies, a general principle, as Yu and Cannella (2007, p. 667) argued, is that the variables to be included in an AMC study have "to impact one or more dimensions of the framework." This suggests that researchers also need to provide additional theoretical explanations for why these variables are related to the specific AMC dimensions. For example, Chen et al. (2007) explained that a firm should pay more attention to its 
competitors with relatively larger scales or sizes, increasing its awareness of the competition from these competitors, while Haleblian et al. (2012) theorized that it should be easier for a firm with higher financial performance to raise the required resources to finance acquisitions, equipping it with a better capability to participate in an acquisition wave.

Following the principle suggested by Yu and Cannella (2007) and taking account of the modern slavery context, our research considers AMC-related variables in terms of media coverage of modern slavery issues, slavery risks in supply chains, and firm performance in corporate sustainability. This is because we expect that firms should be more aware of the importance of addressing supply chain slavery issues when there is greater media coverage of these issues. Moreover, firms sourcing from countries with higher slavery risks should be more motivated to address the issues, while firms with better performance in corporate sustainability should be more capable of addressing them. We formulate these arguments based on the theoretical lenses of agenda-setting theory, expectancy-valence model, and the resource-based view. We provide a more detailed discussion of these arguments in the following section on the development of our hypotheses.

\section{Hypothesis Development}

\subsection{Modern Slavery Media Coverage}

We define modern slavery media coverage as the extent to which modern slavery issues are reported by news media. As we view media coverage as an indication of a focal firm's awareness, we include media coverage of various modern slavery issues without limiting this to those occurring in the focal firm's supply chain. This is because it may be more likely for a focal firm to become aware of the specific modern slavery issues occurring in its supply chain via other means (e.g. supplier audits) rather than via news media (Benstead et al., 2020), making it more difficult to support the awareness view if we just focus on the media coverage of this focal firm's modern slavery issues.

Media coverage has long been an important research topic in the mass communication literature and well-studied through the lens of agenda-setting theory (Luo et al., 2019). Agendasetting theory suggests that when certain issues are covered by news media more frequently and prominently, these issues will be perceived by the public as more important than other issues (McCombs and Shaw, 1972). As Coleman et al. (2009, p. 147) put it, "the more coverage an issue receives, the more important it is to people." This suggests that issue importance or salience can be transferred from the media agenda to the public agenda, which is regarded as the media's public agenda-setting effect (Luo et al., 2019). Previous studies have provided 
consistent, strong empirical support for such a public agenda-setting effect. For example, McCombs and Shaw's (1972) seminal study of the 1968 US presidential election found "a nearly perfect correlation between the media's agenda of issues and the public's agenda of issues" (Coleman et al., 2009, p. 148). A recent meta-analysis conducted by Luo et al. (2019) also showed a large average effect size across different agenda-setting studies.

In addition to increasing audiences' awareness of the issues, media coverage may also make the audiences more aware of "proposed solutions" and "specific knowledge about the proposals" (Benton and Frazier, 1976, p. 261). In our research context, this suggests that media coverage of modern slavery issues may not only increase firms' awareness of the modern slavery issues but also make the firms more aware of possible solutions to address these issues as well as specific knowledge about these solutions, such as the rationales behind these solutions and the advantages and disadvantages of adopting them. This is because the information being covered may vary across news media, with some simply reporting the modern slavery issues but others discussing the possible solutions and consequences, leading to different levels of awareness. Therefore, modern slavery media coverage can be viewed as an awareness-related variable in the modern slavery context. As the AMC framework has suggested that a firm is more likely to act or respond to a threat when it is more aware of the threat (Chen, 1996), we expect modern slavery media coverage to be positively related to firm efforts to address modern slavery in supply chains. As a result, we propose:

Hypothesis 1 (H1). Firms put greater effort into addressing modern slavery in supply chains when there is more intensive media coverage of modern slavery issues.

\subsection{Supply Chain Slavery Risk}

Consistent with prior research that has assessed supply chain risk in terms of the likelihood or probability of adverse supply chain events (Heckmann et al., 2015), we view supply chain slavery risk as the extent to which modern slavery incidents will occur in a focal firm's supply chain. According to the Global Slavery Index, the levels of slavery risk vary across countries (Walk Free Foundation, 2014), suggesting that firms sourcing from suppliers located in different countries should encounter different levels of slavery risks in their supply chains. In this research, we focus on a focal firm's first-tier suppliers because these suppliers, compared with other sub-tier suppliers, are more directly connected and visible to the focal firm and thus more likely to motivate it to address modern slavery. This is in line with our assertion that supply chain slavery risk is a motivation-related variable.

We explain the relationship between supply chain slavery risk and firm motivation to 
address modern slavery in supply chains based on Vroom's (1964) expectancy-valence model of motivation. As indicated by its name, this model suggests that an actor's motivation to act is determined by both valence and expectancy. Valence indicates the perceived reward value associated with an action, while expectancy is the expected probability of earning a reward (Chen and Miller, 1994; Pacheco and Dean, 2015). Therefore, an actor is more motivated to act if it values the potential reward and believes its action can lead to the reward. As Yu and Cannella (2007, p. 666) summarized, "the motivation to respond will be greatest when the potential responder feels that something important is at stake."

In our research context, the outcome valence is greater when a firm faces higher slavery risk in its supply chain. This is because modern slavery incidents are more likely to occur in a highrisk supply chain, and these incidents, once occurring, may result in a significant negative reputational and financial impact on the focal firm (Butler, 2020; Jacobs and Singhal, 2017). This indicates high "potential losses from inaction" (Pacheco and Dean, 2015, p. 1095) in such a supply chain. In contrast, the potential losses from inaction should be lower if there is limited slavery risk in a supply chain. Therefore, the perceived reward value of addressing modern slavery in supply chains is greater for a supply chain with high (rather than low) slavery risk.

Moreover, the effort-outcome expectancy is also greater in a high-risk supply chain. It should be easier for a firm to encounter modern slavery issues in a supply chain with high slavery risk, providing opportunities for the firm to take actions to address the issues and reduce potential losses due to these issues. A firm thus sees a clearer effort-outcome connection in such a supply chain. By contrast, in a supply chain with low slavery risk, modern slavery issues are less likely to occur, making the effort-outcome relationship less clear. Taken together, a firm should be more likely to feel that "something important is at stake" and thus motivated to act when there is high slavery risk in its supply chain. As the AMC framework has linked firm motivation to action (Chen, 1996), we expect a firm to put more effort into addressing modern slavery in a high-risk supply chain. This leads to our second hypothesis:

Hypothesis 2 (H2). Firms sourcing from countries with higher modern slavery risks put greater effort into addressing modern slavery in supply chains.

\subsection{Corporate Sustainability Performance}

Following previous studies that have conceptualized sustainability in terms of the three pillars of people, planet, and profits (Pagell and Gobeli, 2009; Sodhi and Tang, 2021), we regard corporate sustainability performance as a combination or integration of a firm's social, environmental, and financial performance. This notion is in line with the resource-based view 
that "considers a firm as a unique bundle of tangible and intangible resources and capabilities" (Chen, 1996, p. 107), enabling us to view corporate sustainability performance as a capabilityrelated variable in the modern slavery context.

Our explanation of the relationship between corporate sustainability performance and firm capability to address modern slavery in supply chains is grounded on the well-established resource-based view (Barney, 1991). The resource-based view emphasizes that only those resources that are valuable, rare, imperfectly imitable, and non-substitutable (VRIN) can enable firms to gain a competitive advantage (Barney, 1991; Barney and Clark, 2007; Lam et al., 2019). Resources are valuable if they allow firms to exploit opportunities or neutralize threats. Resources are rare if only a small number of firms possess them. Resources are imperfectly imitable if it is costly for firms to acquire or develop them. Finally, resources are nonsubstitutable if they cannot be simply replaced by other strategically equivalent resources.

In this research, we follow Cousins et al. (2020, p. 5283) by viewing "the ability to demonstrate low slavery risk as a competitive advantage for firms." We thus explain why superior performance in corporate sustainability is more likely to lead to the VRIN resources required for firms to achieve this competitive advantage (i.e. low slavery risk in supply chains). First, the resources arising from a firm's superior corporate sustainability performance are valuable for the firm to address modern slavery in its supply chain. For example, firms with good social performance should have more knowledge, experience and skills in resolving social sustainability-related issues (Kim and Davis, 2016), enabling them to apply or adapt the resources they already possess in-house ${ }^{1}$ to address modern slavery issues in supply chains. Similarly, the resources that help firms to improve environmental performance may be transferable to the modern slavery context. Moreover, this environmental knowledge and experience may enable firms to avoid possible unintended environmental consequences resulting from addressing modern slavery issues. Finally, it should be easier for firms with good financial performance to access both internal (e.g. from sales and operations) and external (e.g. from banks and shareholders) financial resources (Haleblian et al., 2012), supporting the firms' investments in addressing modern slavery in supply chains.

The resources discussed above are also rare in the sense that it is uncommon for firms to achieve high performance in all three dimensions of sustainability (social, environmental, and financial). Previous research has also highlighted the tensions among social, environmental,

\footnotetext{
${ }^{1}$ Our measure of social performance excludes supply chain-related data items thereby reducing possible overlaps with modern slavery in supply chains. Please see section 4.2.4 for a more detailed discussion.
} 
and financial performance (McWilliams and Siegel, 2000; Li et al., 2020), indicating the difficulty for firms to balance the three dimensions of corporate sustainability. This also makes these resources imperfectly imitable as the development of the superior corporate sustainability performance and the resultant resources could be path dependent (e.g. the development follows a unique pathway based on the firm's historical conditions) and socially complex (e.g. the development is embedded in the firm's complex, idiosyncratic relationships with different stakeholders). Finally, it is difficult to substitute these resources because the bundle of these social, environmental, and financial resources is important for firms to address modern slavery in supply chains, as discussed above. Taken together, the resources arising from superior performance in corporate sustainability can be regarded as VRIN resources, making firms more capable of addressing modern slavery in supply chains and leading to a competitive advantage in terms of low slavery risk. As the AMC framework has suggested that a firm is more likely to act when it is more capable of acting (Chen, 1996), we expect that a firm is more likely to address modern slavery in its supply chain when it has superior performance in corporate sustainability. This leads to our final hypothesis:

Hypothesis 3 (H3). Firms with better corporate sustainability performance put greater effort into addressing modern slavery in supply chains.

A conceptual framework summarizing the three proposed hypotheses is shown in Figure 1.

-----Figure 1 about here-----

\section{Research Method}

\subsection{Sample and Data Collection}

We constructed our sample based on firms included in the FTSE All-Share Index for several reasons. First, consistent with prior CSR studies that have relied on the CSR or sustainability reports published by firms to assess their CSR efforts or performance (Crilly et al., 2016; Li and Lu, 2020), we relied on firms' modern slavery statements to quantify their efforts to address modern slavery in supply chains. According to the UK MSA, a UK firm with an annual turnover $\geq £ 36$ million is required to publish an annual modern slavery statement (UK Government, 2015). As firms included in this index are publicly listed on the London Stock Exchange (LSE), they are more likely to meet this turnover threshold and enable us to obtain their modern slavery statements for this research. The accounting and financial data of these UK firms are publicly available while these firms are also more likely to be covered by other databases concerned with firms' supply chains and sustainability performance, enabling us to 
use these data sources to measure the relevant variables investigated in this research.

Moreover, this index covers over 600 UK firms across different manufacturing and service industries, representing about $98 \%$ of the market value of all UK firms listed on the LSE and ensuring the generalizability of our research findings (FTSE Russell, 2019). We included firms from service industries in this research because it is common for service firms, especially those listed on the stock markets, to source goods and/or services from overseas suppliers. For example, BT Group, a telecommunications company, stated that it buys "products and services -- such as IT equipment, cables, design and disposal services -- from thousands of suppliers worldwide" (BT Group, 2006). Similarly, HSBC, a large bank, had outsourced parts of its IT support and call centers to suppliers located in developing countries (Griffiths, 2013). Therefore, service firms also need to address modern slavery in their supply chains.

As the UK MSA came into force in 2015 (UK Government, 2015), we started with all 639 firms included in the FTSE All-Share Index in 2015. We searched for these firms' modern slavery statements via BHRRC's Modern Slavery Registry website (www.modernslaveryregistry.org), one of the largest modern slavery statement registers in the world with more than 10,000 statements available. We conducted the data collection in mid2019 when we were able to identify 470 firms (among the 639 firms) with statements available via the website.

We then collected data from multiple additional sources to measure other research variables. In particular, we relied on news articles from Factiva to measure modern slavery media coverage. Factiva aggregates news articles from various UK media outlets such as The Financial Times, Telegraph, and Guardian, enabling us to quantify the annual coverage of modern slavery issues by the UK media (Liu et al., 2014; Chandler et al., 2020). We combined the supply chain relationship data obtained from Factset Revere with the Global Slavery Index published by the Walk Free Foundation to measure supply chain slavery risk. Factset Revere covers the historical supply chain relationships of over 32,000 firms around the world (FactSet, 2014) while the Global Slavery Index ranks the severity of slavery issues across more than 100 countries (Walk Free Foundation, 2014). Taken together, they allowed us to estimate the slavery risk in a sample firm's international supply chain. We aggregated social and environmental performance data from Sustainalytics and financial performance data from Worldscope to measure corporate sustainability performance, which takes account of the three pillars of people, planet, and profits (Sodhi and Tang, 2021). We also used the accounting and financial data from Worldscope to measure other control variables concerned with firm characteristics. 
After combining the data obtained from these sources, 201 firms without missing data across all research variables remained. The descriptive statistics for these 201 firms are shown in Table I. Panel A of the table indicates that about $90 \%$ of the firms published their first modern slavery statement in the 2015 or 2016 fiscal year, while Panel B demonstrates that our sample firms are from various industries. Finally, Panel $\mathrm{C}$ shows that the minimum sales among the sample is $£ 72.2$ million, which is greater than the $£ 36$ million threshold stated in the UK MSA. Although the FTSE All-Share Index does include firms with sales lower than $£ 72.2$ million, these firms were dropped due to missing data from some of the other data sources used in this research, such as Factset Revere and/or Sustainalytics.

-----Table I about here-----

\subsection{Variable Measurements}

The measurements for all the variables investigated in this research, including the dependent, independent, and control variables, are summarized in Table II with more details given below.

-----Table II about here-----

\subsubsection{Modern Slavery Statement Score}

We quantified firms' efforts to address modern slavery in supply chains based on their first modern slavery statements published after the introduction of the UK MSA, for several reasons. First, due to the "illegal, often hidden" (Caruana et al., 2021, p. 258) nature of modern slavery, it is challenging to collect reliable primary data to study modern slavery. A firm's modern slavery statement is the best data source available for us to make sense of its effort to address modern slavery issues. This is because such a statement, issued under the UK MSA, should document the steps taken by a firm to "ensure that slavery and human trafficking is not taking place in any of its supply chains" (Home Office, 2017, p. 5). Prior CSR research (e.g. Crilly et al., 2016; Li and Lu, 2020) has also relied on firms' CSR or sustainability reports to assess their CSR efforts or performance. For instance, Crilly et al. (2016) measured Chinese firms' efforts to "do good" and "do no harm" by analyzing the content of these firms' sustainability reports. Similarly, we analyzed the content of firms' modern slavery statements to quantify their efforts to address modern slavery, but our analysis was based on a Python program rather than human judgment. This can help avoid human bias or preference and ensure an objective assessment of the modern slavery statements. Moreover, as firms may learn from one another as they gain more experience in issuing modern slavery statements, leading to possible homogenization in documenting efforts to address modern slavery (Stevenson and Cole, 2018), our analysis 
focused on firms' first modern slavery statements to reduce this potential bias.

The UK MSA suggests that a firm's modern slavery statement can include information about its: (1) structure, business and supply chains; (2) policies related to slavery and human trafficking; (3) due diligence processes related to slavery and human trafficking in the business and supply chains; (4) the parts of the business and supply chains where there is a risk of slavery and human trafficking taking place, and the steps taken to assess and manage that risk; (5) its effectiveness in ensuring that slavery and human trafficking is not taking place in the business or supply chains; and, (6) the training about slavery and human trafficking available to staff. We thus analyzed our sample firms' modern slavery statements based on these six suggested categories. Specifically, we first formulated coding principles for these six categories, as shown in the Appendix, and developed a Python program using these principles to auto-code our sample firms' statements. For instance, for category (f) regarding modern slavery and human trafficking training, our program assigned 2 points to a firm if its statement mentioned training and modern slavery/human trafficking-related keywords in a sentence. If only the training keyword was mentioned without modern slavery/human trafficking-related keywords in the same sentence, 1 point was assigned by the program. Finally, the program assigned 0 points to a firm if the training keyword could not be found across the text of its statement.

A firm's score in each category was calculated as the percentage of the number of points obtained by the firm in this category divided by the maximum number of points available in the same category. For example, as the maximum number of points available in category (f) is 2, if a firm obtains 1 point in this category, its score in this specific category will be $50 \%$ (i.e. 1 divided by 2). Finally, we computed the statement score for each sample firm as its average percentage score across the six categories. We found that the average statement score across the 201 sample firms is $50 \%$, with a very high standard deviation of $20 \%$. In fact, the statement scores for these firms ranged from $0 \%$ to $91 \%$, demonstrating the heterogeneity of firms' efforts to address slavery issues in supply chains.

We further verified our program-coded statement scores based on other data sources and measurement approaches. Specifically, we first obtained the data from Development International, who assessed the anti-slavery/human trafficking performance of FTSE 100 companies based on modern slavery statements (Bayer et al., 2018). We then matched our sample with those covered by Development International, resulting in 71 matched firms. Finally, we computed the correlation between our program-coded statement scores and the performance scores obtained from Development International for these 71 firms. The correlation is highly positive and significant $(r=0.42, p<0.01)$. Moreover, we also coded our 
sample firms' modern slavery statements manually and obtained a high correlation between the human- and program-coded statement scores (further explained in section 5.1). These additional checks confirmed the reliability and validity of our program-coded statement scores.

\subsubsection{Modern Slavery Media Coverage}

Consistent with prior research (e.g. Liu et al., 2014; Chandler et al., 2020), we measured media coverage by searching relevant news articles via Factiva. We preferred Factiva to a specific newspaper (e.g. Financial Times) because Factiva aggregated news articles from various media sources, thereby representing a more comprehensive coverage of the modern slavery topic under study. Factiva also allowed us to restrict our search to those media sources based in the UK, in line with our research context focused on UK firms. As we were interested in the overall coverage of the modern slavery topic rather than the modern slavery issues of specific firms, we used "modern slavery" as the search keyword without including the names of specific companies. We limited our search to the headlines of news articles because these news articles should be more relevant to modern slavery, compared with other news articles mentioning "modern slavery" in their bodies rather than headlines. Prior research also suggested that news headlines are used to highlight important information and grab readers' attention (Geer and Kahn, 1993), consistent with our awareness view on media coverage. After the search, we quantified modern slavery media coverage in each year as the annual number of news articles from UK media mentioning "modern slavery" in their headlines.

\subsubsection{Supply Chain Slavery Risk}

We combined data from Factset Revere and Walk Free Foundation to measure the slavery risk in each sample firm's supply chain. Specifically, we relied on Factset Revere's historical supply chain relationship data to identify a sample firm's first-tier suppliers and their countries in the year before the sample firm issued its first modern slavery statement (FactSet, 2014), while the slavery risk at the country level was indicated by the Global Slavery Index published by the Walk Free Foundation in 2014 (Walk Free Foundation, 2014). To account for the possibility that a sample firm's suppliers may be distributed unevenly across countries, we created a weighted variable, $w_{i}$, to indicate the percentage of a sample firm's suppliers in each country $i$. Mathematically, we computed a sample firm's supply chain slavery risk as $\sum_{i=1}^{N} w_{i} \times$ Global Slavery Index $x_{i}$ where $w_{i}$ is the ratio of a sample firm's number of suppliers in country $i$ to the same firm's total number of suppliers across $N$ countries. Although this measure does not capture the actual 
slavery incidents associated with a sample firm's suppliers, it represents the perceived slavery risk in the firm's supply chain. This is because a firm should be more likely to encounter supply chain slavery issues if its suppliers are located in countries with high (rather than low) slavery risks as indicated by the Global Slavery Index.

\subsubsection{Corporate Sustainability Performance}

We measured corporate sustainability performance as a combination of a firm's social, environmental, and financial performance (Pagell and Gobeli, 2009; Sodhi and Tang, 2021). First, we obtained social and environmental performance data from Sustainalytics, a database monitoring the annual nonfinancial performance of more than 11,000 firms across different countries (including the UK) based on information from various primary and secondary sources (Thorne et al., 2017; Francoeur et al., 2019). For example, Sustainalytics tracks 58 and 56 data items related to social and environmental performance, respectively (Walker et al., 2019). For each data item, Sustainalytics rates firm performance from 0 to 100 , with a higher value indicating a better performance. As a firm's social performance may have incorporated modern slavery in its supply chain, leading to possible tautological concerns, we excluded 10 supply chain-related data items, such as quality of social supply chain standards and external social certification of suppliers, when measuring social performance. This means that we measured our sample firms' social and environmental performance as the average ratings of their 48 (i.e. 58-10) social-related data items and 56 environmental-related data items, respectively.

We measured a firm's annual financial performance in terms of its return on assets (ROA) (Kim and Davis, 2016; Thorne et al., 2017). Specifically, with the annual accounting data obtained from Worldscope, we computed ROA as operating income divided by total assets. We rescaled ROA to the range of 0 to 100 to make it consistent with the measures of social and environmental performance. Finally, we averaged a sample firm's social, environmental, and financial performance to obtain an overall measure of its corporate sustainability performance.

\subsubsection{Control Variables}

We controlled for several firm-level variables, including firm size, the market to book (MTB) ratio, labor intensity, and domestic sales, that may be related to firms' efforts to address slavery issues. Specifically, firm size and domestic sales may be positively related to firm efforts because large firms may have more resources to address slavery issues while firms with more domestic sales may pay more attention to UK domestic markets and the UK MSA. By contrast, MTB ratio and labor intensity may be negatively related to firm efforts. A firm with a higher MTB ratio is perceived as more valuable by shareholders and expected to have a higher growth 
in the future, which may force the firm to allocate resources to other investments (rather than to address modern slavery) in order to maintain a high growth rate. A firm with a higher labor intensity relies more on laborers rather than machines, which may be more likely to encounter slavery issues. We measured firm size as the natural logarithm of the number of employees (Kim et al., 2015), the MTB ratio as the market value of equity divided by the book value of equity (Lam, 2018), labor intensity as the number of employees divided by sales (Yiu et al., 2020), and domestic sales as the percentage of UK sales divided by the total sales (Short et al., 2007).

\subsection{Regression Analysis}

We constructed a regression model, as shown below, to estimate how modern slavery media coverage $(\mathrm{H} 1)$, supply chain slavery risk $(\mathrm{H} 2)$, and corporate sustainability performance $(\mathrm{H} 3)$, are related to firms' statement scores.

Statement Score $_{i(t+1)}$

$=\alpha_{0}+\alpha_{1}$ Firm Size $_{i t}+\alpha_{2}$ MTB Ratio $_{i t}+\alpha_{3}$ Labor Intensity $_{i t}+\alpha_{4}$ Domestic Sales $_{i t}$

$+\alpha_{5}$ Modern Slavery Media Coverage $e_{i t}+\alpha_{6}$ Supply Chain Slavery Risk $k_{i t}$

$+\alpha_{7}$ Corporate Sustainability Performance ${ }_{i t}+\varepsilon_{i t}$,

where $i$ and $t$ are firm and year indices, respectively. $\varepsilon_{i t}$ is the error term. We maintained a oneyear lag between the dependent variable measured in year $t+1$ and all independent variables measured in year $t$, ensuring the direction of causality under test. Also, the dependent and independent variables were measured based on data collected from different sources such as Factset Revere, Worldscope, and Sustainalytics, reducing possible common method bias. We have also conducted several robustness tests based on alternative measures of the dependent and independent variables and obtained consistent test results, as documented in Section 5.1. The highest variance inflation factor values across all independent variables is 1.30 , which is well below the threshold of 5 and suggests multicollinearity is not a major concern (Kim et al., 2016). As we measured firms' statement scores based on their first modern slavery statements, this is a cross-sectional rather than a panel regression model. We thus performed an ordinary least squares estimation of the model and relied on $\alpha_{5}$ to $\alpha_{7}$, respectively, to test the three hypotheses.

\section{Test Results}

The correlations, means, and standard deviations of all variables included in the regression model are presented in Table III, while Table IV shows the test results of four regression 
models with different combinations of independent variables. Specifically, Model 1 includes control variables only. Models 2 to 4 add the three hypothesized variables (i.e. modern slavery media coverage, supply chain slavery risk, and corporate sustainability performance) to Model 1 sequentially. All four models are statistically significant $(p<0.01)$ with adjusted $R$-squared values ranging from $9.00 \%$ to $17.31 \%$.

-----Tables III and IV about here-----

The coefficient of modern slavery media coverage remains positive and significant $(p<0.1)$ across models 2 to 4 , suggesting that firms put more effort into addressing slavery issues in supply chains when there is more media coverage of these issues. Thus, H1 is supported. Similarly, the coefficient of the supply chain slavery risk is positive and significant $(p<0.05)$ in models 3 to 4 . This means that firms sourcing products from suppliers located in countries with high slavery risks put more effort into addressing slavery issues in supply chains, thereby supporting H2. Finally, the coefficient of corporate sustainability performance is positive and significant $(p<0.01)$, as shown in Model 4. This suggests that firms with better performance in corporate sustainability put more effort into addressing slavery issues in supply chains, supporting H3. Therefore, all three hypotheses are supported.

Moreover, three control variables, i.e. firm size, MTB ratio, and domestic sales, are statistically significant $(p<0.1)$ in the full mode (i.e. Model 4). Specifically, the test results suggest that firms of a larger size, with higher domestic sales but lower MTB ratios put more effort into addressing slavery issues in supply chains, which is consistent with our expectation.

\subsection{Robustness Tests}

We conducted several additional tests to check the robustness of our findings and documented the test results in Table V. First, we adopted alternative measures of the three hypothesized variables. Specifically, we measured modern slavery media coverage alternatively based on news articles from the 12 most circulated daily newspapers in the UK (Tobitt and Majid, 2021) rather than from all UK media sources, accounting for the possibility that UK firms may pay more attention to these major newspapers. For supply chain slavery risk, instead of using the Global Slavery Index published in 2014, our alternative measure was based on the average value of the Global Slavery Index published between 2014 and 2018, which took account of the fact that our sample firms issued their first modern slavery statements across different years between 2015 and 2018. Finally, we measured corporate sustainability performance alternatively by focusing on the environmental and financial performance dimensions (i.e. we excluded the social performance dimension), further addressing the concern that the social 
performance dimension may have covered modern slavery. The regression results based on these three alternative measures remain consistent, as shown in Models 1 to 3 in Table V, respectively.

\section{-----Table V about here-----}

We employed the instrumental variables (IV) approach to further address the possible endogenous relationship between corporate sustainability performance and statement score. Following previous studies (e.g. Ho et al., 2017; Fu et al., 2020), we first instrumented a firm's corporate sustainability performance with two variables: (1) the average corporate sustainability performance of the firm's industry peers, and (2) the firm's three-year lagged corporate sustainability performance. We then performed a two-stage least squares estimation using these two instruments and obtained consistent test results, as shown in Model 4. This suggests that our model specification is robust to endogeneity concerns.

To further investigate how individual dimensions of corporate sustainability performance are related to firm efforts to address modern slavery in supply chains, we decomposed corporate sustainability performance into social, environmental, and financial performance and included these three dimensions as independent variables in the regression model. The regression results documented in Model 5 suggest that while the social $(p<0.05)$ and environmental $(p<0.1)$ dimensions are still positively related to statement score, there is no significant relationship ( $p$ $>0.1)$ between the financial dimension and statement score. This investigation reveals the heterogeneity of relationships between different types of firm performance and firm efforts to address modern slavery in supply chains.

Our analysis has focused on firms' first modern slavery statements in order to mitigate possible mimetic isomorphism issues, but this practice raises the concern that these first statements, compared with more recent ones, might be less sophisticated in documenting the firms' efforts to address modern slavery (Benstead et al., 2018). To address this concern, we conducted one-way ANOVA tests to check the difference in statement scores across different issuing years (2015-2018) but could not find a significant difference $(p>0.1)$. We also performed multiple-comparison tests to compare the differences in statement scores between 2015 and each of the other years, but we still did not identify any significant differences $(p>$ 0.1). Overall, there is no evidence that the statement scores vary significantly across years. Nevertheless, we measured the dependent variable alternatively as the average score of a firm's modern slavery statements issued between 2015 and 2018 and obtained qualitatively similar regression results, as shown in Model 6. 
Finally, we remeasured firm efforts to address modern slavery in supply chains based on human (rather than machine) coding. Specifically, two of the authors read the modern slavery statements of all sample firms independently and rated each statement based on a five-point scale, ranging from 1 (little effort to address modern slavery) to 5 (major effort to address modern slavery). The ratings from the two independent coders were consistent, as indicated by the very high correlation between their ratings $(r=0.87, p<0.01)$. We thus averaged the ratings from the two coders to indicate firms' overall efforts. We also checked and confirmed a high correlation between the human- and machine-coded ratings $(r=0.48, p<0.01)$. Finally, we obtained consistent regression results in Model 7 with the human-coded ratings as the dependent variable.

\section{Discussion of Test Results}

Our test results show that firms put more effort into addressing supply chain modern slavery issues when there is greater media coverage of these issues. This finding can be explained by agenda-setting theory (Luo et al., 2019), which suggests that media coverage makes firms more aware of the importance of addressing modern slavery issues, which in turn translates into their efforts to address these issues. Although media coverage receives limited attention from SCM researchers, it has been well investigated in previous CSR studies (Zyglidopoulos et al., 2012; Pollach, 2014). For example, Pollach (2014) found that media coverage of environmental issues is related to firms' environmental agendas, which is consistent with our finding regarding the impact of media coverage on firm efforts to address modern slavery.

Our test results further suggest that a firm's efforts to address modern slavery are also determined by the slavery risk presented in its supply chain. This is because firms should be more likely to encounter modern slavery issues in supply chains with high (rather than low) slavery risk, motivating them to take actions to address these issues and avoid "potential losses from inaction" (Pacheco and Dean, 2015, p. 1095). This explanation is in line with the expectancy-valence model, which emphasizes that an actor is more motivated to act when it "feels that something important is at stake" (Yu and Cannella, 2007, p. 666). Previous SCM studies, although not focused on modern slavery, have also highlighted how firm practices are dependent on supply chain risk. For instance, Awaysheh and Klassen (2010) found that a firm is more likely to adopt supplier socially responsible practices when it runs a long, risky supply chain, which is consistent with our finding regarding the determining role of supply chain slavery risk.

Moreover, our test results reveal the positive relationship between corporate sustainability 
performance and firm efforts to address modern slavery in supply chains. We attribute this finding to the fact that firms with superior performance in corporate sustainability should possess more knowledge, experience and skills in resolving social and environmental issues and have easier access to internal and external financial resources, equipping them with better capabilities for addressing modern slavery in supply chains. This logic is in line with the resource-based view which considers the bundle of these social, environmental, and financial resources as a source for firms to gain a competitive advantage in terms of "the ability to demonstrate low slavery risk" (Cousins et al., 2020, p. 5283). Interestingly, our robustness tests further suggest that social and environmental resources are more important than financial resources for firms to gain such a competitive advantage. This finding is consistent with the possible tension between financial performance and CSR activities highlighted in the literature (McWilliams and Siegel, 2000; Li et al., 2020). Although firms with better financial performance should have more resources to address modern slavery, they may face greater pressure to maintain high financial performance and prefer to allocate their resources to other investments (rather than addressing modern slavery) with clear, foreseeable financial returns, making financial performance less relevant to firm efforts to address modern slavery.

Although not hypothesized, several control variables, including firm size, domestic sales, and MTB ratio, are found to be significantly related to firm efforts to address modern slavery in supply chains. The findings of these variables can still be interpreted through the AMC framework. For example, firm size can be viewed as a capability-related variable, suggesting that large firms should have more resources and capabilities to address modern slavery in their supply chains. Meanwhile, domestic sales and MTB ratio can be related to firm motivation. Specifically, firms with more domestic sales in the UK should pay more attention to the UK market and the UK MSA, motivating them to address slavery issues to meet UK customers' expectations and UK government's demands. By contrast, firms with a high MTB ratio are expected by shareholders to have a high growth rate, motivating them to allocate their resources to those investments that are more likely to meet shareholders' expectations (rather than to address modern slavery in supply chains).

\section{Conclusions, Contributions and Limitations}

To conclude, by utilizing the AMC framework and the theoretical lenses of agenda-setting theory, the expectancy-valence model, and the resource-based view, our research theorizes how AMC-related factors, including modern slavery media coverage, supply chain slavery risk, and corporate sustainability performance, help explain the variation in firms' efforts to address 
modern slavery in supply chains. Consistent with our theorization, our empirical analysis, based on secondary data collected from multiple sources, suggests that firms put more effort into addressing supply chain modern slavery issues when there is greater media coverage of these issues, when firms source from countries with high slavery risks, and when firms have good performance in corporate sustainability. Our research provides important implications for theory and practices.

\subsection{Theoretical Implications}

Our research contributes to the modern slavery literature by adopting the AMC framework to explain why firms put different efforts into addressing modern slavery in supply chains. Although prior studies have documented the variation in firms' efforts to address modern slavery (Stevenson and Cole, 2018; Flynn and Walker, 2021), they "struggle to explain it", as pointed out by Monciardini et al. (2021, p. 290). The AMC framework enables us to make sense of such variation by considering a firm's awareness, motivation, and capability of addressing modern slavery issues. The consideration of the three dimensions of awareness, motivation, and capability also allows us to provide a more comprehensive explanation of the determinants of the firms' efforts. Our research demonstrates the applicability of the AMC framework in the modern slavery context, laying an important theoretical foundation for future research. In particular, future research can adopt the AMC framework to investigate AMCrelated factors at different levels (e.g. firm, supply chain, industry, and country), advancing our understanding of firm behaviors in the modern slavery context.

Moreover, our research enriches the AMC literature by employing relevant theories, including agenda-setting theory, the expectancy-valence model, and the resource-based view, to further theorize how the variables under study are related to the specific AMC dimensions. Although the AMC framework provides an overarching, meta-theoretic perspective for researchers to consider AMC-related variables, it fails to explain why these variables are related to the specific AMC dimensions and thus can be viewed as AMC-related variables. Previous AMC studies have also often made the connections between their research variables

and the specific AMC dimensions based on implicit assumptions or common sense. Our research, by contrast, relies on formal theorization, providing a clear link between empirical constructs and theoretical concepts. For instance, we use agenda-setting theory to explain why firms are more aware of the importance of addressing supply chain slavery issues when there is greater media coverage of these issues, enabling us to view media coverage as an awarenessrelated variable in the modern slavery context. Our formal theorization approach is also in line 
with Yu and Cannella's (2007, p. 667) suggestion that researchers need to explain how the variables to be included in an AMC study "impact one or more dimensions of the framework." Overall, our research highlights the importance of integrating the AMC framework with other relevant theories, together enabling a solid, theoretical explanation of the AMC-related variables and advancing the AMC literature.

Finally, our research reveals new theoretical insights by comparing different capabilityrelated variables. Specifically, our research shows that the social, environmental, and financial dimensions of corporate sustainability are related to firm efforts to address modern slavery to different extents. This suggests that although firms with superior performance in these dimensions should possess more resources that enable them to address modern slavery, the importance of these dimensions is not the same in the modern slavery context. Our research thus extends the resource-based view by arguing that although VRIN resources enable firms to create competitive advantage (Barney, 1991), the advantage-creating potentials should vary across different types of VRIN resources. In other words, we should not assume the same advantage-creating potentials for different VRIN resources. Our investigation also responds to Gold et al.'s (2015, p. 491) call for studying “which resources and capabilities need to be developed within individual companies" for addressing modern slavery, inspiring future research to further compare different AMC-related variables. For instance, researchers may reveal new insights by examining the variation across different media outlets (e.g. newspapers, radio, television, and social media) in influencing firms' awareness of modern slavery issues.

\subsection{Practical Implications}

Consistent with prior studies (Stevenson and Cole, 2018; Flynn and Walker, 2021), our analysis of UK firms' modern slavery statements finds significant variation in their efforts to address modern slavery in supply chains. This may explain why existing modern slavery-related legislation, such as the UK MSA, has been criticized for being ineffective at ensuring firms genuinely address modern slavery issues (Ionova, 2018; Cousins et al., 2020). There is no doubt that much should be done to tackle modern slavery, and our research provides important implications for different stakeholders, as outlined below.

Our research demonstrates a positive relationship between media coverage and firm efforts to address supply chain modern slavery issues. This suggests that news media should realize their agenda-setting role, regularly covering relevant modern slavery topics to increase firms' awareness of the importance of addressing modern slavery in supply chains. Other parties, such as governments and NGOs, can also use news media to make firms more aware of "proposed 
solutions" and "specific knowledge about the proposals" (Benton and Frazier, 1976, p. 261), moving beyond a general awareness of modern slavery issues. For example, they can use news media to discuss different practices to address modern slavery as well as the pros and cons of these practices, taking advantage of the media's public agenda-setting effect (Luo et al., 2019).

Our research also shows that firms perceiving there to be a higher risk of modern slavery in their supply chains are more likely to address the threat. This implies that governments and relevant parties can highlight the risks and negative consequences of modern slavery issues to motivate firms to act. This can be done through, for example, public education, investigation reports, and dedicated reporting websites (e.g. www.modernslavery.gov.uk). A general insight emerging from our investigation is that a firm is more motivated to act when it "feels that something important is at stake" (Yu and Cannella, 2007, p. 666). This suggests that governments could use both carrot and stick approaches to motivate firms to address modern slavery. For instance, a firm's performance in addressing modern slavery could become part of the criteria for obtaining governmental contracts, and the private sector could be encouraged to also follow this practice. Similarly, the government and private sector could adopt a zerotolerance policy, terminating contracts with firms when modern slavery is found in their supply chains.

However, policymakers should realize that not all firms have the necessary capabilities to address modern slavery issues, especially when these issues occur in extended supply chains. Our research also suggests that it is unlikely that firms with poor performance in corporate sustainability are able to address modern slavery in their supply chains. It is thus important to provide appropriate support to enable firms to build the necessary capabilities, such as to improve their sustainability performance. Firms themselves should also not underestimate the difficulty of addressing modern slavery in supply chains whilst understanding the transferability of the knowledge, experience and skills gained from corporate sustainability improvements to the modern slavery context. Therefore, we encourage firms to improve their performance in corporate sustainability, which in turn will make them more capable of addressing modern slavery in supply chains.

Other stakeholders, such as customers and shareholders, can also play important roles in motivating firms to address supply chain modern slavery issues. For example, our research shows that firms put more effort into addressing slavery issues when they have more sales from the UK. This suggests that UK customers, who "seek out businesses with higher ethical standards" (Home Office, 2017, p. 4), expect firms to address modern slavery in their supply chains. By contrast, our research suggests that firms with a high MTB ratio are less likely to 
address supply chain slavery issues as these firms may perceive that their shareholders expect them to focus on high-growth investments rather than on addressing slavery issues. Therefore, shareholders of these firms may have to voice their expectation of slavery-free supply chains, changing the firms' perceptions and encouraging them to address supply chain slavery issues.

\subsection{Research Limitations}

As with any research, our study has certain limitations. The first limitation concerns the sample of firms used in our research. In particular, we constructed the sample based on the FTSE AllShare Index, which may limit the generalizability of our findings to public limited firms only. Moreover, due to missing data across different sources, the firms included in this research are relatively large, with minimum sales equal to $£ 72.2$ million, which is approximately double the threshold required by the UK MSA. Thus, our findings may not be applicable to smaller firms whose characteristics and capabilities may be quite different to those in our sample. We thus encourage future research to investigate other private and smaller firms to verify the conclusions drawn in our research. It would also be interesting to look at samples from other countries that have introduced similar legislation, such as from Australia or France.

Moreover, our measurements based on secondary data are not perfect. For instance, we quantified firms' efforts based on a content analysis of their modern slavery statements. Although this approach is consistent with prior CSR research (Crilly et al., 2016; Li and Lu, 2020) and we verified it with a third-party source and a manual coding approach, it is possible that firms' modern slavery statements may not fully reflect their true efforts to address slavery issues as firms have the freedom to decide what to disclose in their statements. Modern slavery statements also limit our focus to firms with a turnover $\geq £ 36$ million as only these firms are required to issue such statements. We thus encourage future research to adopt other approaches, such as in-depth case studies, to cover firms with different turnovers and provide a more complete documentation of their efforts to address modern slavery.

Another measurement limitation is that we relied on a firm's first-tier suppliers for measuring the slavery risk in its supply chain. Although this measurement approach is in line with our motivation argument, it misses the opportunity of looking at a firm's sub-tier suppliers that may be more likely to be involved in modern slavery incidents. Therefore, future research can explore the possibility of using other datasets to study slavery risk in multi-tier supply chains and reveal new insights. 


\section{References}

Anti-Slavery International (2020), "Leaving no-one behind: Guidance for policymakers, donors and business leaders to ensure that responses to Covid-19 reach victims of modern slavery and people vulnerable to slavery", https://www.antislavery.org/wpcontent/uploads/2020/04/ASI_Leaving-noone-behind-April-20201.pdf?mc_cid=e744db66e5\&mc_eid=96ce13ad78 (Accessed: 12 April 2021).

Arya, B. and Zhang, G. (2009), "Institutional reforms and investor reactions to CSR announcements: Evidence from an emerging economy", Journal of Management Studies, Vol. 46 No. 7, pp. 1089-1112.

Awaysheh, A. and Klassen, R.D. (2010), "The impact of supply chain structure on the use of supplier socially responsible practices", International Journal of Operations \& Production Management, Vol. 30 No. 12, pp. 1246-1268.

Barney, J.B. (1991), "Firm resources and sustained competitive advantage", Journal of Management, Vol. 17 No. 1, pp. 99-120.

Barney, J.B. and Clark, D.N. (2007), Resource-based theory: Creating and sustaining competitive advantage, New York: Oxford University Press.

Bayer, C., Margherita, M., Vogel, G. and Xu, J. (2018), GLOBAL GOVERNANCE: Compliance and conformance with U.K. MSA and good practice in human rights, Germany: Development International.

Benstead, A.V., Hendry, L.C. and Stevenson, M. (2018), "Horizontal collaboration in response to modern slavery legislation: An action research project", International Journal of Operations \& Production Management, Vol. 38 No. 12, pp. 2286-2312.

Benstead, A.V., Hendry, L.C. and Stevenson, M. (2020), "Detecting and remediating modern slavery in supply chains: A targeted audit approach", Production Planning \& Control, Forthcoming, https://doi.org/10.1080/09537287.2020.1795290.

Benton, M. and Frazier, P.J. (1976), "The agenda setting function of the mass media at three levels of "information holding"”, Communication Research, Vol. 3 No. 3, pp. 261-274.

BHRRC (2017), "First Year of FTSE 100 Reports under the UK Modern Slavery Act: Towards Elimination?",

https://media.businesshumanrights.org/media/documents/files/FTSE_100_Report_FINAL_0021Dec2017.pdf (Accessed: 14 May 2021).

Brockhaus, S., Fawcett, S.E., Hobbs, S. and Schwarze, A.S. (2019), "Boldly going where firms have gone before? Understanding the evolution of supplier codes of conduct", The International Journal of Logistics Management. Vol. 30 No. 3, pp. 743-771.

BT Group (2006), "Suppliers”, https://www.bt.com/bt-plc/assets/documents/digital-impactand-sustainability/our-report/report-archive/2006/suppliers.pdf (Accessed: 6 November 2021).

Butler, S. (2020), "Boohoo shares drop 18\% as new Leicester factory reports threaten sales", https://www.theguardian.com/business/2020/jul/13/boohoo-shares-drop-18-as-newleicester-factory-reports-threaten-sales (Accessed: 12 April 2021).

Carrington, M., Chatzidakis, A. and Shaw, D. (2021), "Consuming worker exploitation? Accounts and justifications for consumer (In)action to modern slavery", Work, Employment and Society, Vol. 35 No.3, pp. 432-450.

Caruana, R., Crane, A., Gold, S. and LeBaron, G. (2021), "Modern slavery in business: the sad 
and sorry state of a non-field", Business \& Society, Vol. 60 No. 2, pp. 251-287.

Chandler, D., Polidoro, F. and Yang, W. (2020), "When is it good to be bad? Contrasting effects of multiple reputations for bad behavior on media coverage of serious organizational errors", Academy of Management Journal, Vol. 63 No. 4, pp. 1236-1265.

Chen, M.J. (1996), "Competitor analysis and interfirm rivalry: Toward a theoretical integration”, Academy of Management Review, Vol. 21 No. 1, pp. 100-134.

Chen, M.J. and Miller, D. (1994), "Competitive attack, retaliation and performance: An expectancy-valence framework", Strategic Management Journal, Vol. 15 No. 2, pp. 85-102.

Chen, M.J., Su, K.H. and Tsai, W. (2007), "Competitive tension: The awareness-motivationcapability perspective”, Academy of Management Journal, Vol. 50 No. 1, pp. 101-118.

Coleman, R., McCombs, M., Shaw, D. and Weaver, D. (2009), “Agenda setting”. In K. WahlJorgensen and T. Hanitzsch (Eds.), The Handbook of Journalism Studies (pp. 147-160), New York, NY: Routledge.

Cousins, P., Dutordoir, M., Lawson, B. and Neto, J.Q.F. (2020), "Shareholder wealth effects of modern slavery regulation”, Management Science, Vol. 66 No. 11, pp. 4921-5484.

Craighead, C.W., Ketchen, D.J. and Darby, J.L. (2020), "Pandemics and supply chain management research: toward a theoretical toolbox", Decision Sciences, Vol. 51 No. 4, pp. 838-866.

Crane, A. (2013), "Modern slavery as a management practice: Exploring the conditions and capabilities for human exploitation", Academy of Management Review, Vol. 38 No. 1, pp. 49-69.

Crilly, D., Ni, N. and Jiang, Y. (2016), "Do-no-harm versus do-good social responsibility: Attributional thinking and the liability of foreignness", Strategic Management Journal, Vol. 37 No. 7, pp. 1316-1329.

FactSet (2014), "FactSet Supply Chain Relationships", https://open.factset.com/products/factset-supply-chain-relationships/en-us (Accessed: 12 April 2021).

Flynn, A. and Walker, H. (2021), "Corporate responses to modern slavery risks: an institutional theory perspective", European Business Review, Vol. 33 No. 2, pp. 295-315.

Francoeur, C., Labelle, R., Balti, S. and Bouzaidi, S.E. (2019), "To what extent do gender diverse boards enhance corporate social performance?", Journal of Business Ethics, Vol. 155 No. 2, pp. 343-357.

FTSE Russell (2019), Ground Rules for the FTSE UK Index Series, London, UK: FTSE Russell.

Fu, R., Tang, Y. and Chen, G. (2020), "Chief sustainability officers and corporate social (ir)responsibility”, Strategic Management Journal, Vol. 41 No. 4, pp. 656-680.

Geer, J.G. and Kahn, K.F. (1993), "Grabbing attention: An experimental investigation of headlines during campaigns", Political Communication, Vol. 10 No. 2, pp. 175-191.

Gold, S., Trautrims, A. and Trodd, Z. (2015), "Modern slavery challenges to supply chain management", Supply Chain Management, Vol. 20 No. 5, pp. 485-494.

Griffiths, K. (2013), "HSBC to outsource 4,000 UK bank jobs to Asia", https://www.independent.co.uk/news/business/news/hsbc-to-outsource-4-000-uk-bankjobs-to-asia-91762.html (Accessed: 6 November 2021).

Haleblian, J., McNamara, G., Kolev, K. and Dykes, B.J. (2012), "Exploring firm characteristics 
that differentiate leaders from followers in industry merger waves: A competitive dynamics perspective”, Strategic Management Journal, Vol. 33 No. 9, pp. 1037-1052.

Heckmann, I., Comes, T. and Nickel, S. (2015), "A critical review on supply chain riskDefinition, measure and modeling”, Omega, Vol. 52, pp. 119-132.

Ho, T.H., Lim, N., Reza, S. and Xia, X. (2017), "Causal inference models in operations management”, Manufacturing \& Service Operations Management, Vol. 19 No. 4, pp. 509525 .

Home Office (2017), "Transparency in Supply Chains: A practical guide", https://assets.publishing.service.gov.uk/government/uploads/system/uploads/attachment_d ata/file/649906/Transparency_in_Supply_Chains_A_Practical_Guide_2017.pdf

(Accessed: 20 November 2021).

Ionova, A. (2018), "Is landmark UK law falling short in fight against modern slavery?", https://uk.reuters.com/article/us-britain-slavery-law/is-landmark-uk-law-fallingshort-in-fight-against-modern-slavery-idUSKBN1GV07V (Accessed: 12 April 2021).

Jacobs, B.W. and Singhal, V.R. (2017), "The effect of the Rana Plaza disaster on shareholder wealth of retailers: Implications for sourcing strategies and supply chain governance", Journal of Operations Management, Vol. 49, pp. 52-66.

Kim, H., Hur, D. and Schoenherr, T. (2015), "When buyer-driven knowledge transfer activities really work: A motivation-opportunity-ability perspective", Journal of Supply Chain Management, Vol. 51 No. 3, pp. 33-60.

Kim, Y.H. and Davis, G.F. (2016), "Challenges for global supply chain sustainability: Evidence from conflict minerals reports", Academy of Management Journal, Vol. 59 No. 6, pp. 1896-1916.

Lam, H.K. (2018), "Doing good across organizational boundaries: Sustainable supply chain practices and firms' financial risk", International Journal of Operations \& Production Management, Vol. 38 No.12, pp. 2389-2412.

Lam, H.K., Yeung, A.C., Lo, C.K. and Cheng, T.C.E. (2019), "Should firms invest in social commerce? An integrative perspective", Information \& Management, Vol. 56 No. 8, pp. 118.

Li, J., Yin, J., Shi, W. and Yi, X. (2020), "Keeping up with the joneses: Role of CSR awards in incentivizing non-winners' CSR”, Business \& Society, Forthcoming, https://doi.org/10.1177\%2F0007650320982271.

Li, S. and Lu, J.W. (2020), "A dual-agency model of firm CSR in response to institutional pressure: Evidence from Chinese publicly listed firms", Academy of Management Journal, Vol. 63 No. 6, pp. 2004-2032.

Liu, L.X., Sherman, A.E. and Zhang, Y. (2014), "The long-run role of the media: Evidence from initial public offerings", Management Science, Vol. 60 No. 8, pp. 1945-1964.

Luo, Y., Burley, H., Moe, A. and Sui, M. (2019), “A meta-analysis of news media's public agenda-setting effects, 1972-2015”, Journalism \& Mass Communication Quarterly, Vol. 96 No. 1, pp. 150-172.

Mani, V., Jabbour, C.J.C. and Mani, K.T. (2020), "Supply chain social sustainability in small and medium manufacturing enterprises and firms' performance: Empirical evidence from an emerging Asian economy", International Journal of Production Economics, Vol. 227, pp. 1-13. 
McCombs, M.E. and Shaw, D.L. (1972), "The agenda-setting function of mass media", Public Opinion Quarterly, Vol. 36 No. 2, pp. 176-187.

McWilliams, A. and Siegel, D. (2000), "Corporate social responsibility and financial performance: Correlation or misspecification?”, Strategic Management Journal, Vol. 21 No. 5, pp. 603-609.

Meehan, J. and Pinnington, B.D. (2021), "Modern slavery in supply chains: insights through strategic ambiguity", International Journal of Operations \& Production Management, Vol. 41 No. 2, pp. 77-101.

Monciardini, D., Bernaz, N. and Andhov, A. (2021), "The organizational dynamics of compliance with the UK Modern Slavery Act in the food and tobacco sector", Business \& Society, Vol. 60 No. 2, pp. 288-340.

New, S.J. (2015). "Modern slavery and the supply chain: the limits of corporate social responsibility?", Supply Chain Management, Vol. 20 No. 6, pp. 697-707.

Pacheco, D.F. and Dean, T.J. (2015), "Firm responses to social movement pressures: A competitive dynamics perspective", Strategic Management Journal, Vol. 36 No. 7, pp. 1093-1104.

Pagell, M. and Gobeli, D. (2009), “How plant managers' experiences and attitudes toward sustainability relate to operational performance", Production and Operations Management, Vol. 18 No. 3, pp. 278-299.

Pollach, I. (2014), "Corporate environmental reporting and news coverage of environmental issues: An agenda-setting perspective", Business Strategy and the Environment, Vol. 23 No. 5, pp. 349-360.

Rogerson, M., Crane, A., Soundararajan, V., Grosvold, J. and Cho, C.H. (2020), "Organisational responses to mandatory modern slavery disclosure legislation: a failure of experimentalist governance?", Accounting, Auditing \& Accountability Journal, Vol. 33 No. 7, pp. 1505-1534.

Short, J.C., Ketchen, D.J., Palmer, T.B. and Hult, G.T.M. (2007), "Firm, strategic group, and industry influences on performance", Strategic Management Journal, Vol. 28 No. 2, pp. 147-167.

Sodhi, M.S. and Tang, C.S. (2021), "Extending AAA capabilities to meet PPP goals in supply chains", Production and Operations Management, Vol. 30 No. 3, pp. 625-632.

Stevenson, M. and Cole, R. (2018), "Modern slavery in supply chains: a secondary data analysis of detection, remediation and disclosure", Supply Chain Management, Vol. 23 No. 2, pp. 81-99.

Such, E., Jaipaul, R. and Salway, S. (2020), "Modern slavery in the UK: How should the health sector be responding?”, Journal of Public Health, Vol. 42 No. 1, pp. 216-220.

Thorne, L., Mahoney, L.S., Gregory, K. and Convery, S. (2017), "A comparison of Canadian and US CSR strategic alliances, CSR reporting, and CSR performance: Insights into implicit-explicit CSR", Journal of Business Ethics, Vol. 143 No. 1, pp. 85-98.

Tobitt, C. and Majid, A. (2021), "National Press ABCs", https://pressgazette.co.uk/mostpopular-newspapers-uk-abc-monthly-circulation-figures/ (Accessed: 31 October 2021).

Udenio, M., Hoberg, K. and Fransoo, J.C. (2018), "Inventory agility upon demand shocks: Empirical evidence from the financial crisis", Journal of Operations Management, Vol. 62, pp. 16-43. 
UK Government (2015), "Modern Slavery Act 2015", http://www.legislation.gov.uk/ukpga/2015/30/contents (Accessed: 12 April 2021).

Vroom, V.H. (1964), Work and Motivation, New York: Wiley.

Walk Free Foundation (2014), “Global Slavery Index 2014”, https://reporterbrasil.org.br/wpcontent/uploads/2014/11/GlobalSlavery_2014_LR-FINAL.pdf (Accessed: 12 April 2021).

Walker, K., Zhang, Z. and Ni, N. (2019), "The Mirror effect: Corporate social responsibility, corporate social irresponsibility and firm performance in coordinated market economies and Liberal market economies", British Journal of Management, Vol. 30 No. 1, pp. 151-168.

Yawar, S.A. and Seuring, S. (2017), "Management of social issues in supply chains: a literature review exploring social issues, actions and performance outcomes", Journal of Business Ethics, Vol. 141 No. 3, pp. 621-643.

Yiu, L.D., Lam, H.K., Yeung, A.C., and Cheng, T.C.E. (2020), "Enhancing the financial returns of R\&D investments through operations management", Production and Operations Management, Vol. 29 No. 7, pp. 1658-1678.

$\mathrm{Yu}, \mathrm{T}$. and Cannella, A.A. (2007), "Rivalry between multinational enterprises: An event history approach", Academy of Management Journal, Vol. 50 No. 3, pp. 665-686.

Zyglidopoulos, S.C., Georgiadis, A.P., Carroll, C.E. and Siegel, D.S. (2012), "Does media attention drive corporate social responsibility?", Journal of Business Research, Vol. 65 No. 11, pp. 1622-1627. 


\section{Appendix: Coding of Firms' Modern Slavery Statements}

a) The organization's structure, its business and its supply chains:

Code 0 : if there is no information about the firm's structure, business and supply chains.

Code 1: if there is information about the firm's structure and/or business.

Code 2: if there is information about the firm's supply chains as well as its structure and/or business.

b) Its policies in relation to slavery and human tracking:

Code 0: if there is no information about the firm's code of conduct or policy.

Code 1: if there is information about the firm's code of conduct or policy.

Code 2: if the code of conduct or policy mentioned is directly related to modern slavery.

c) Its due diligence processes in relation to slavery and human tracking in its business and supply chains:

Count the firm's number of due diligence activities as suggested by the CORE Coalition (https://corporate-responsibility.org/publications/mandatory-human-rights-duediligence/).

d) The parts of its business and supply chains where there is a risk of slavery and human tracking taking place, and the steps taken to assess and manage that risk;

Code 0 : if there is no information about risk analysis or risk assessment.

Code 1: if there is information about risk analysis or risk assessment.

Code 2: if the risk analysis or risk assessment mentioned is directly related to modern slavery.

e) Its effectiveness in ensuring that slavery and human tracking is not taking place in its business or supply chains, measured against such performance indicators as it considers appropriate:

Code 0: if there is no information about the firm's effectiveness.

Code 1: if there are general statements on the firm's effectiveness.

Code 2: if there are specific KPIs measuring the firm's effectiveness.

f) The training about slavery and human tracking available to its staff:

Code 0: if there is no information about the firm's training activities.

Code 1: if there is information about the firm's training activities in general.

Code 2: if the firm's training activities mentioned are directly related to modern slavery. 


\begin{tabular}{|c|c|c|}
\hline Awareness & \multirow{2}{*}{$\mathrm{H} 1(+)$} & \multirow{8}{*}{$\begin{array}{c}\text { A Firm's } \\
\text { Effort to } \\
\text { Address } \\
\text { Modern } \\
\text { Slavery } \\
\text { in its } \\
\text { Supply } \\
\text { Chain }\end{array}$} \\
\hline Modern Slavery Media Coverage & & \\
\hline & \multirow{3}{*}{$\mathrm{H} 2(+)$} & \\
\hline Motivation & & \\
\hline Supply Chain Slavery Risk & & \\
\hline & \multirow{2}{*}{$\mathrm{H} 3(+)$} & \\
\hline Capability & & \\
\hline Corporate Sustainability Performance & & \\
\hline
\end{tabular}

Figure 1. Conceptual Framework 
Table I. Descriptive Statistics

\begin{tabular}{|c|c|c|c|}
\hline \multicolumn{4}{|c|}{ Panel A: Distribution of sample firms' first statements across years } \\
\hline Year & Frequency & & Percentage \\
\hline 2015 & 86 & & $42.8 \%$ \\
\hline 2016 & 94 & & $46.8 \%$ \\
\hline 2017 & 15 & & $7.5 \%$ \\
\hline 2018 & 6 & & $3.0 \%$ \\
\hline All Years & 201 & & $100 \%$ \\
\hline \multicolumn{4}{|c|}{ Panel B: Distribution of sample firms across industries } \\
\hline Industry & SIC Code & Frequency & Percentage \\
\hline Mining & $10-14$ & 15 & $7.5 \%$ \\
\hline Construction & $15-17$ & 7 & $3.5 \%$ \\
\hline Manufacturing & $20-39$ & 50 & $24.9 \%$ \\
\hline $\begin{array}{l}\text { Transportation, Communications, } \\
\text { Electric, Gas, and Sanitary Services }\end{array}$ & $40-49$ & 26 & $12.9 \%$ \\
\hline Wholesale Trade & $50-51$ & 11 & $5.5 \%$ \\
\hline Retail Trade & $52-59$ & 29 & $14.4 \%$ \\
\hline Finance, Insurance, and Real Estate & $60-67$ & 32 & $15.9 \%$ \\
\hline Services & $70-89$ & 31 & $15.4 \%$ \\
\hline All Industries & All SIC Codes & 201 & $100 \%$ \\
\hline
\end{tabular}

Panel C: Characteristics of sample firms

\begin{tabular}{ccccc}
\hline Firm characteristics & Mean & Standard deviation & Minimum & Maximum \\
Sales (million) & 5947.0 & 13573.0 & 72.2 & 146167.2 \\
Total assets (million) & 28978.7 & 148962.9 & 189.6 & 1629644.0 \\
Operating income (million) & 558.1 & 1316.5 & -5827.0 & 10645.1 \\
Number of employees (thousand) & 31.2 & 72.5 & 0.02 & 611.4 \\
Return on assets (\%) & 7.3 & 8.4 & -32.0 & 39.9 \\
Return on sales (\%) & 14.4 & 12.8 & -35.8 & 64.9 \\
\hline
\end{tabular}


Table II. Variable Measurements

\begin{tabular}{|c|c|c|}
\hline Variables & Measurements & Data Sources \\
\hline Statement Score & 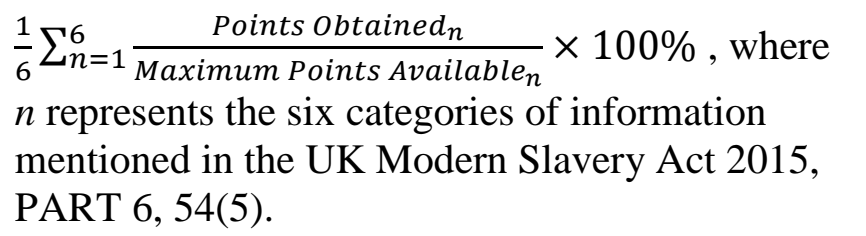 & $\begin{array}{l}\text { Modern Slavery } \\
\text { Registry }\end{array}$ \\
\hline $\begin{array}{l}\text { Modern Slavery } \\
\text { Media Coverage }\end{array}$ & $\begin{array}{l}\text { Annual number of UK news articles covering } \\
\text { modern slavery issues }\end{array}$ & Factiva \\
\hline $\begin{array}{l}\text { Supply Chain } \\
\text { Slavery Risk }\end{array}$ & $\begin{array}{l}\sum_{i=1}^{N} w_{i} \times G S I_{i} \text {, where } w_{i} \text { represents the ratio of a } \\
\text { firm's number of suppliers in country } i \text { to the same } \\
\text { firm's total number suppliers across } N \text { countries, } \\
\text { and } G S I_{i} \text { indicates country } i \text { 's Global Slavery Index } \\
\text { published by the Walk Free Foundation in } 2014 \text {. }\end{array}$ & $\begin{array}{l}\text { Factset Revere, } \\
\text { Walk Free } \\
\text { Foundation }\end{array}$ \\
\hline $\begin{array}{l}\text { Corporate } \\
\text { Sustainability } \\
\text { Performance }\end{array}$ & $\begin{array}{l}\text { The average of a firm's social performance } \\
\text { (excludes supply chain data items and ranges } \\
\text { from } 0 \text { to } 100 \text { ), environmental performance } \\
\text { (ranges from } 0 \text { to } 100 \text { ), and financial performance } \\
\text { (return on assets; rescaled to } 0 \text { to } 100 \text { ). }\end{array}$ & $\begin{array}{l}\text { Worldscope, } \\
\text { Sustainalytics }\end{array}$ \\
\hline Firm Size & Natural logarithm of number of employees & Worldscope \\
\hline MTB Ratio & $\begin{array}{l}\text { Market value of equity divided by book value of } \\
\text { equity }\end{array}$ & Worldscope \\
\hline Labor Intensity & Number of employees divided by sales & Worldscope \\
\hline Domestic Sales & $\frac{\text { UK Sales }}{\text { Total Sales }} \times 100 \%$ & Worldscope \\
\hline
\end{tabular}


Table III. Correlation Matrix

\begin{tabular}{lllllllll}
\hline Variables & 1 & 2 & 3 & 4 & 5 & 6 & 7 & 8 \\
\hline 1. Statement Score & 1.00 & & & & & & & \\
2. Firm Size & $0.28 * * *$ & 1.00 & & & & & & \\
3. MTB Ratio & -0.07 & 0.03 & 1.00 & & & & & \\
4. Labor Intensity & 0.02 & $0.41 * * *$ & 0.05 & 1.00 & & & & \\
5. Domestic Sales & 0.03 & $-0.20 * * *$ & -0.01 & -0.04 & 1.00 & & & \\
6. Modern Slavery & 0.11 & -0.04 & 0.03 & -0.12 & $-0.13 *$ & 1.00 & & \\
Media Coverage & & & & & & & & \\
7. Supply Chain & $0.17 * *$ & $0.18 * *$ & 0.08 & -0.04 & $-0.41 * * *$ & 0.07 & 1.00 & \\
Slavery Risk & & & & & & & & \\
8. Corporate Sustainability & $0.24 * * *$ & 0.03 & 0.11 & -0.08 & $0.13 *$ & -0.03 & -0.02 & 1.00 \\
Performance & & & & & & & & \\
Mean & 49.76 & 2.15 & 3.93 & 7.10 & 52.75 & 242.46 & 20.87 & 56.92 \\
Standard deviation & 20.23 & 1.74 & 6.77 & 8.76 & 38.39 & 136.55 & 5.94 & 7.82 \\
\hline Notes: * $p<0.1, * * p<0.05$, and & $* * * p<0.01$ (two-tailed tests). & & & & \\
\hline
\end{tabular}


Table IV. Regression Results

\begin{tabular}{|c|c|c|c|c|}
\hline Variables & Model 1 & Model 2 & Model 3 & Model 4 \\
\hline Intercept & $\begin{array}{c}40.96^{* * *} \\
(12.65)\end{array}$ & $\begin{array}{c}35.50 * * * \\
(8.25)\end{array}$ & $\begin{array}{c}20.91 * * * \\
(2.92)\end{array}$ & $\begin{array}{l}-11.29 \\
(-0.97)\end{array}$ \\
\hline Firm Size & $\begin{array}{c}4.15 * * * \\
(4.72)\end{array}$ & $\begin{array}{c}4.19 * * * \\
(4.79)\end{array}$ & $\begin{array}{c}3.88 * * * \\
(4.46)\end{array}$ & $\begin{array}{c}3.62 * * * \\
(4.26)\end{array}$ \\
\hline MTB Ratio & $\begin{array}{c}-0.23 \\
(-1.16)\end{array}$ & $\begin{array}{c}-0.25 \\
(-1.23)\end{array}$ & $\begin{array}{c}-0.28 \\
(-1.44)\end{array}$ & $\begin{array}{l}-0.36^{*} \\
(-1.86)\end{array}$ \\
\hline Labor Intensity & $\begin{array}{c}-0.28 \\
(-1.63)\end{array}$ & $\begin{array}{c}-0.25 \\
(-1.44)\end{array}$ & $\begin{array}{c}-0.20 \\
(-1.16)\end{array}$ & $\begin{array}{c}-0.13 \\
(-0.81)\end{array}$ \\
\hline Domestic Sales & $\begin{array}{c}0.05 \\
(1.45)\end{array}$ & $\begin{array}{l}0.06^{*} \\
(1.70)\end{array}$ & $\begin{array}{c}0.10 * * \\
(2.56)\end{array}$ & $\begin{array}{c}0.08 * * \\
(2.12)\end{array}$ \\
\hline Modern Slavery Media Coverage & & $\begin{array}{l}0.02 * \\
(1.91)\end{array}$ & $\begin{array}{l}0.02 * \\
(1.90)\end{array}$ & $\begin{array}{c}0.02 * * \\
(2.05)\end{array}$ \\
\hline Supply Chain Slavery Risk & & & $\begin{array}{c}0.63 * * \\
(2.52)\end{array}$ & $\begin{array}{c}0.62 * * \\
(2.54)\end{array}$ \\
\hline Corporate Sustainability Performance & & & & $\begin{array}{c}0.59 * * * \\
(3.47)\end{array}$ \\
\hline Number of Observations & 201 & 201 & 201 & 201 \\
\hline$R$-squared & $10.82 \%$ & $12.45 \%$ & $15.23 \%$ & $20.20 \%$ \\
\hline Adjusted $R$-squared & $9.00 \%$ & $10.21 \%$ & $12.61 \%$ & $17.31 \%$ \\
\hline$F$-statistic & $5.94 * * *$ & $5.55^{* * *}$ & $5.81 * * *$ & $6.98 * * *$ \\
\hline
\end{tabular}

Notes: $* p<0.1, * * p<0.05$, and $* * * p<0.01$ (two-tailed tests). $t$-statistics are in parentheses. A one-year lag between the dependent variable (Statement Score) and all the independent variables. 
Table V. Robustness Test Results

\begin{tabular}{|c|c|c|c|c|c|c|c|}
\hline Variables & $\begin{array}{c}\text { Model } \\
1\end{array}$ & $\begin{array}{c}\text { Model } \\
2\end{array}$ & $\begin{array}{l}\text { Model } \\
3\end{array}$ & $\begin{array}{c}\text { Model } \\
4\end{array}$ & $\begin{array}{c}\text { Model } \\
5\end{array}$ & $\begin{array}{l}\text { Model } \\
6\end{array}$ & $\begin{array}{l}\text { Model } \\
7\end{array}$ \\
\hline Intercept & $\begin{array}{l}-10.23 \\
(-0.88)\end{array}$ & $\begin{array}{l}-12.33 \\
(-1.05)\end{array}$ & $\begin{array}{l}-4.56 \\
(-0.39)\end{array}$ & $\begin{array}{l}-10.37 \\
(-0.73)\end{array}$ & $\begin{array}{l}-9.17 \\
(-0.75)\end{array}$ & $\begin{array}{l}-9.38 \\
(-0.81)\end{array}$ & $\begin{array}{c}-1.51 * * \\
(-2.43)\end{array}$ \\
\hline Firm Size & $\begin{array}{c}3.63 * * * \\
(4.26)\end{array}$ & $\begin{array}{c}3.60 * * * \\
(4.24)\end{array}$ & $\begin{array}{c}3.67 * * * \\
(4.27)\end{array}$ & $\begin{array}{c}3.61 * * * \\
(4.02)\end{array}$ & $\begin{array}{c}3.57 * * * \\
(4.01)\end{array}$ & $\begin{array}{c}3.56 * * * \\
(4.22)\end{array}$ & $\begin{array}{c}0.34 * * * \\
(7.44)\end{array}$ \\
\hline MTB Ratio & $\begin{array}{l}-0.36^{*} \\
(-1.83)\end{array}$ & $\begin{array}{l}-0.36^{*} \\
(-1.86)\end{array}$ & $\begin{array}{l}-0.37 * \\
(-1.86)\end{array}$ & $\begin{array}{l}-0.36^{*} \\
(-1.83)\end{array}$ & $\begin{array}{c}-0.33 \\
(-1.59)\end{array}$ & $\begin{array}{l}-0.33^{*} \\
(-1.69)\end{array}$ & $\begin{array}{l}-0.01 \\
(-1.44)\end{array}$ \\
\hline Labor Intensity & $\begin{array}{l}-0.14 \\
(-0.85)\end{array}$ & $\begin{array}{c}-0.14 \\
(-0.86)\end{array}$ & $\begin{array}{l}-0.13 \\
(-0.79)\end{array}$ & $\begin{array}{c}-0.12 \\
(-0.71)\end{array}$ & $\begin{array}{l}-0.14 \\
(-0.86)\end{array}$ & $\begin{array}{l}-0.05 \\
(-0.33)\end{array}$ & $\begin{array}{l}-0.01 \\
(-1.39)\end{array}$ \\
\hline Domestic Sales & $\begin{array}{l}0.08 * * \\
(2.08)\end{array}$ & $\begin{array}{c}0.08 * * \\
(2.02)\end{array}$ & $\begin{array}{l}0.10 * * \\
(2.48)\end{array}$ & $\begin{array}{l}0.10 * * \\
(2.33)\end{array}$ & $\begin{array}{l}0.08 * * \\
(2.00)\end{array}$ & $\begin{array}{l}0.08 * * \\
(2.01)\end{array}$ & $\begin{array}{c}0.004 * * \\
(2.11)\end{array}$ \\
\hline $\begin{array}{l}\text { Modern Slavery Media } \\
\text { Coverage }\end{array}$ & $\begin{array}{l}0.04 * \\
(1.85)\end{array}$ & $\begin{array}{l}0.02 * * \\
(2.01)\end{array}$ & $\begin{array}{l}0.02 * * \\
(2.13)\end{array}$ & $\begin{array}{c}0.03 * * * \\
(2.83)\end{array}$ & $\begin{array}{l}0.02 * \\
(1.96)\end{array}$ & $\begin{array}{l}0.02 * \\
(1.93)\end{array}$ & $\begin{array}{l}0.002 * * * \\
(3.77)\end{array}$ \\
\hline $\begin{array}{l}\text { Supply Chain Slavery } \\
\text { Risk }\end{array}$ & $\begin{array}{l}0.61 * * \\
(2.52)\end{array}$ & $\begin{array}{l}0.71 * * \\
(2.60)\end{array}$ & $\begin{array}{c}0.68 * * * \\
(2.75)\end{array}$ & $\begin{array}{l}0.62 * * \\
(2.48)\end{array}$ & $\begin{array}{l}0.59 * * \\
(2.34)\end{array}$ & $\begin{array}{l}0.54 * * \\
(2.24)\end{array}$ & $\begin{array}{l}0.02 * \\
(1.88)\end{array}$ \\
\hline $\begin{array}{l}\text { Corporate Sustainability } \\
\text { Performance }\end{array}$ & $\begin{array}{c}0.59 * * * \\
(3.47)\end{array}$ & $\begin{array}{c}0.58 * * * \\
(3.39)\end{array}$ & $\begin{array}{l}0.43 * * * \\
(2.72)\end{array}$ & $\begin{array}{l}0.52 * * \\
(2.36)\end{array}$ & & $\begin{array}{c}0.61 * * * \\
(3.61)\end{array}$ & $\begin{array}{c}0.04 * * * \\
(4.08)\end{array}$ \\
\hline Social Performance & & & & & $\begin{array}{l}0.26 * * \\
(2.15)\end{array}$ & & \\
\hline $\begin{array}{l}\text { Environmental } \\
\text { Performance }\end{array}$ & & & & & $\begin{array}{l}0.18^{*} \\
(1.68)\end{array}$ & & \\
\hline Financial Performance & & & & & $\begin{array}{c}0.14 \\
(1.10)\end{array}$ & & \\
\hline Number of Observations & 201 & 201 & 201 & 180 & 201 & 201 & 201 \\
\hline$R$-squared & $19.89 \%$ & $20.33 \%$ & $18.36 \%$ & $21.40 \%$ & $20.38 \%$ & $19.81 \%$ & $34.30 \%$ \\
\hline Adjusted $R$-squared & $16.98 \%$ & $17.44 \%$ & $15.40 \%$ & $18.21 \%$ & $16.63 \%$ & $16.90 \%$ & $31.92 \%$ \\
\hline$F$-statistic & $6.84 * * *$ & $7.04 * * *$ & $6.20 * * *$ & $6.16 * * *$ & $5.43 * * *$ & $6.81 * * *$ & $14.39 * * *$ \\
\hline
\end{tabular}

Notes: ${ }^{*} p<0.1, * * p<0.05$, and $* * * p<0.01$ (two-tailed tests). $t$-statistics are in parentheses. A one-year lag between the dependent variable (Statement Score) and all the independent variables. Model 1: measure modern slavery media coverage alternatively by focusing on 12 major UK newspapers. Model 2: measure supply chain slavery risk alternatively based on the average value of the Global Slavery Index published between 2014 and 2018. Model 3: measure corporate sustainability performance alternatively by focusing on the environmental and financial performance dimensions (i.e. exclude the social performance dimension). Model 4: treat corporate sustainability performance as an endogenous variable and perform two-stage least squares estimation based on the instrumental variables approach. Model 5: show the three individual dimensions of corporate sustainability performance. Model 6: measure the dependent variable alternatively based on average statement score from 2015 to 2018. Model 7: measure the dependent variable alternatively based on manual coding of statements. 